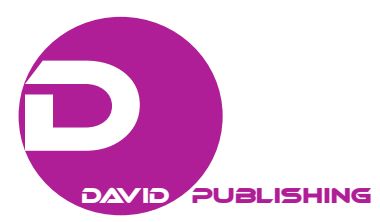

\title{
Different Scenarios of Property Taxation Reforms in Italy: Two Compared Proposals
}

\author{
Fernando Di Nicola \\ Ministry of Economy and Finances, Rome, Italy \\ Ruggero Paladini \\ University “La Sapienza”, Rome, Italy
}

\begin{abstract}
Starting from the premise that Italian real estate taxation is inefficient and unnecessarily complex, the paper suggests two tax reforms. The first proposal puts forward progressive property taxation on the family basis; the second one suggests inferring a property income within the general calculation of the personal income tax. The common features of the two tax schemes are: the use of property market values instead of cadastral rents, a general reduction of the real estate local tax, a strong cutback of the stamp duties and registration fees applied to real estate transfers. A microsimulation model is employed to evaluate the impacts of the proposed taxation schemes. They both show, providing for a constant tax revenue, stronger redistributive effects.
\end{abstract}

Keywords: real estate taxation, local tax, redistribution, personal income tax

\section{Introduction}

Over the last few years, Italian policy maker has frequently changed property taxation, first and foremost with a view to raising an extra tax revenue and overlooking the traditional criteria of equity and effectiveness. As a consequence, property taxation is fragmented and ineffective.

In Italy, property taxation is made up of different kind of taxes. It includes personal income taxes, value added taxes, stamp duties, inheritance and gift taxes, local property, and additional income taxes (IMU, TASI, Local surtax called Addizionale Irpef). The taxation financing services provided by the local administrations (such as public lighting, maintenance of roads, etc.) are actually based on the possession, under any legal title, of a real estate.

As far as equity is concerned, this property taxation scheme is partially inconsistent, in consequence of the variety of tax assumptions: income, property, and transactions. Moreover, from the point of view of efficiency, the tax burden on transactions is quite heavy; as a result, the allocation of properties is not effective and does not adapt to a fast-moving economic environment. Finally, taking into account the benefit principle the present property taxation scheme is not optimal.

This paper attempts to evaluate and compare two different reforms of the present Italian property taxation scheme, taking into account both local and state taxation. The first proposal suggests calculating the tax base

Fernando Di Nicola, Fiscal policies advisor in Department of Finance, Ministry of Economy and Finances, Rome, Italy.

Ruggero Paladini, professor of Finance, University “La Sapienza”, Rome, Italy.

Correspondence concerning this article should be addressed to Fernando Di Nicola, presso Dipartimento delle Finanze MEF, via dei Normanni, 5, 00184 Roma, Italy. 
using the market values of properties and applying a progressive tax to the household wealth. The second one proposes to include the "notional" market rents in the total tax base which the PIT (personal income tax) (Italian Irpef) is applied to.

The first proposal takes inspiration from the Meade's Report (1989) and the more recent works of Piketty (2014). The second one is rooted in the comprehensive income tax approach.

Common traits of the two proposals are the use of market values both for property values and incomes, a rationalisation of local property and income taxation, a reduction of taxes on property transfers, providing for an overall real estate tax burden similar to the one applied on other kind of incomes, in relation to both the incidence and the redistributive effect.

It would be worthy to extend the analysis of a fiscal reform including other real and financial assets, or concerning personal taxation; for example, a personal income tax might be compared with a personal tax on spending, but it is not the aim of this paper. Nevertheless, the weight of real estate taxation upon different taxpayers justifies the analysis and reflection; the results may be interesting in terms of economic effects.

\section{The Literature on Local and State Property Taxation}

\section{A Progressive Wealth Tax}

Piketty (2014) suggests introducing a progressive wealth tax, aiming at an effective redistribution together

with the desired tax revenue. It would integrate or substitute the comprehensive income tax on property. Piketty, Saez, and Stantcheva (2013) conveniently underline (probably in relation to the financial assets) that a wealth tax may be more effective if it is applied at a supranational level, for example in large geographical area such as USA or Europe. In this case, it would be necessary to have a full exchange of information among countries, in order to prevent that people divert their profits and incomes to "tax heavens".

In detail, Piketty proposes to apply a zero tax rate (that is a personal tax free allowance threshold) to the net wealth adding up to one million euros; a tax rate equal to $1 \%$, from one to five million; a tax rate equal to $2 \%$, above five million. In this way, it would be possible to implement a progressive tax rate, with an increasing incidence on the net wealth ( $0.5 \%$ on two million, $0.75 \%$ on four million, $1 \%$ on six million and so on). The incidence is thus fast increasing above one million; then it grows more slowly, tending to $2 \%$, without ever reaching it. The wealth tax so designed would raise a tax revenue equal to $2 \%$ of GDP (in Italy almost 30 billion euros); as it is levied on a small percentage of taxpayers (2.5\%) but owing $40 \%$ of wealth (wealth is more concentrated than income).

In Europe, France is the country where a wealth tax is actually applied. The wealth tax is payable if you have total worldwide net assets in excess of $€ 1,300,000$, a threshold that is inflation linked. The thresholds and tax rates applied are five and come from $0.5 \%$ to $1.5 \%$. The tax revenue raised is equal, on average, almost to four billion euros. The tax revenue potentially expected from a Piketty wealth tax would be 10 times higher and it would represent $2 \%$ of French GDP. This is clearly due to the level of Piketty tax rates higher than the actual wealth tax rate applied in France. When the threshold up to which taxpayers did not pay the wealth tax was 800,000 and the higher marginal tax rate was $1.8 \%$, the tax revenue was almost equal to four billion as well, as the fair market value of an owner occupying main home could be reduced by $30 \%$ (before the abatement was 20\%). As a consequence, if a flat's value was one million euros, the owner had the possibility to save from 500 to 1,500 euros. Moreover, the tax liability on income and the solidarity tax were capped to a maximum of 50\% of household total income. The reform of the wealth tax, reducing higher marginal tax rates from 1.8 to 1.5 and 
increasing the exemption threshold from 800,000 to $1,300,000$, has not had relevant effects in terms of tax revenue.

A significant variable to be taken into account is tax evasion, in particular the diversion of wealth—especially financial capital—to more fiscally advantageous countries (for example Switzerland, or tax heavens). For example, it has been estimated that Italian capital diverted to Switzerland amount to 180 billion; and the probability that they are assets exceeding one million euros is very high. Last but not least, tax allowances play a relevant role, reducing the net value of the tax base (assets). Beyond the $30 \%$ abatement for the value of the main residence, not theoretically justified, in the light of the high exemption threshold, other tax reliefs are established. For example, the pactes d'actionnaires reduce significantly tax liability if shareholders commit to keeping their shares for a specified period. Shareholders—asking to benefit from the pactes d'actionnaires - are often owners of companies and therefore they possess high value assets. Tax reliefs - in this case-aim at reducing tax liability on production activities or fostering savings used to finance production activities.

French wealth tax undoubtedly makes the fiscal system more progressive and equitable. However, to make the wealth tax more effective it would be necessary to cancel the present tax allowances; a positive effect would be a double tax burden but companies would be adversely affected especially companies whose ownership is very concentrated.

When French policy maker introduced the solidarity tax the aim was to prevent negative effects against production activities. In general, an alternative way to make more progressive and equitable the fiscal system would be the information exchange among countries, suggested by Piketty, Saez, and Stantcheva (2013). It would permit to actually implement a comprehensive income tax; in other words, a tax is levied on all incomes earned by the taxpayer, including capital gains. The redistributive effect would be prominent and tax rates would not need to be so high. Nevertheless, to reach the required level of wealth disclosure is a great challenge: it needs time and political will.

\section{A Progressive Personal Income Tax and Redistribution Issues}

During the two World Wars, a progressive taxation was designed to reduce income disparity first in Anglo-Saxon countries, then in central Europe. The notion of a comprehensive income tax was developed for the first time by Simons (1938) and Vickrey (1947), even if no country has actually implemented the theoretical concept of "comprehensive income". A tax on spending is the alternative to a comprehensive income tax described in detail by Meade’s Report (1978). He proposes to levy taxes on private expenditures, assets, and cash flow corporate income. Meade's tax design received a lot of attention in the 1980s, but then it was not implemented fully and rigorously, even if it probably affected the EET system ${ }^{1}$.

A fervent discussion on the potential introduction of a progressive personal income tax was developed between the 19th and 20th centuries. It had both fervent supporters and severe detractors. Actually, progressive taxes with very high top marginal tax rates were introduced after the First World War. Various arguments in favour of progressivity were advanced; the most influential issue was elaborated by Carver and Edgeworth in the late 19th century. Then, the notion was further developed by Pigou, within the utilitarian theory of social welfare. According to this approach, it was fair to levy a 100\% tax rate to the portion of income exceeding the

\footnotetext{
${ }^{1}$ A form of taxation of pension plans, whereby contributions are exempt, investment income and capital gains of the pension fund are also exempt and benefits are taxed from personal income taxation (OECD, 2005).
} 
average income and to redistribute it to lower incomes. However, as Pigou's progressive tax could create strong work disincentive effects; it cleared the convenience to adjust progressively tax rates in order to avoid too high levels (near 100\%).

Some liberals supported the introduction of a progressive taxation, while, as underlined by Vincenzo Visco (2014), at first the socialist movement, interested in a change of social system and production modes, did not pay attention to redistribution issues as a way to reach a greater equity. When the social-democratic movement evolved and accepted the reformist ideas, the relevance of fiscal policy in building a fair welfare state was recognised. Scandinavian countries represent a good example of this historical process.

At the end of the 1960s, some economists attempted to give suggestions about the design of an effective fiscal system, both in relation to consumption and income taxation. The basic idea is to apply microeconomics approach to fiscal issues in order to design optimal taxation systems. "Optimal" means that the taxation system has to maximise the collective welfare. In lots of countries, the higher tax rates were in the range of 80-90\%, while in USA they were even higher.

At the end of the 1970s, all the adjustments made to fiscal systems by Anglo-Saxon countries and countries in Western Europe reduced the redistributive effect of fiscal withdrawal. In particular, lots of empirical studies show the progressive reduction of higher tax rates, within the progressive taxation schemes.

At the beginning of the 1980s, Hall and Rabushka (1983) advocated the introduction of a flat rate, as low as possible (initially 19\%). A general fixed subsidy was replaced by a deduction for dependent workers, aiming at guaranteeing a sufficient level of progressivity. The flat tax was first proposed, in USA, within the 1986 fiscal reform but it had a limited impact. On the contrary, it was actually implemented by the ex-communist countries, in the 1990s. The 1986 fiscal reform, in USA, was approved in September by the two-third majority in both houses of Parliament, made up of almost the same percentage of Republicans and Democrats. The tax base of the personal income tax was broadened, including capital gains and abolishing some deductions, while the number of tax rates was drastically shrunk: two tax rates were formally established (14\% and $28 \%)$, but actually three tax rates were operated (33\%).

Recently, new and different hypothesis has emerged together with the flat tax approach, in the general framework of optimal taxation, supporting a higher progressivity of taxation systems, as in Piketty, Saez, and Stantcheva (2013), De Vincenti and Paladini (2009), and Saez (2001).

In Italy, the personal income tax (Irpef) was introduced afterward and the tax base was lower than a comprehensive income tax base, both for legal exclusion and tax evasion. Further components have recently been excluded from the personal income tax base, especially in relation to property incomes, currently subject to the local property taxation and the proportional substitute $\operatorname{tax}^{2}$. As a consequence, the general structure of property tax is not optimal in terms of both vertical and horizontal equity and effective marginal tax rates are not rationally modulated. In addition, cadastral rents are not updated within property market values, especially luxury real estate; therefore, the whole property taxation scheme is invalidated.

Finally, as far as property taxation is concerned, in certain circumstances capital gains are not taxed (INVIM); in other words, tax burden is paid by the "buyer" rather than by the "owner" who earns capital gains. In addition, taxation on property transfers and donations is very high.

\footnotetext{
${ }^{2}$ Financial incomes (the most relevant and traditional incomes), minimum taxpayers, the flat tax on property income (cedolare secca) the substitute taxation on productivity premiums are further examples of incomes excluded from the progressive personal income tax.
} 
During the last 30 years, the personal income tax progressivity is slightly increased, for lots of factors: first of all, between 1978 and 1998, fiscal drag and the growth of real incomes caused that most taxpayers belonging to $1 \%$ moved to higher tax brackets (even if, from 1998, the higher marginal tax rate has progressively shrank, now being equal to $43 \%{ }^{3}$ ). Second, some deductions were transformed into tax credits; in addition, tax credit percentages have become lower and lower. Nevertheless, the portion of private expenses deductible from the gross tax has also diminished. By 1991, deductible expenditures concerning health and medical expenses, interests paid on mortgages, life insurance premiums, expenses for education, for example, could guarantee a tax saving equal to taxpayer's marginal tax rate. According to the new rules now in force, taxpayers may deduct $19 \%$ of the related expense up to a certain cap. As the tax rate (19\%) and the cap are equal for all taxpayers, the incidence of tax savings on incomes is decreasing. In addition, the expense caps are not linked to the inflation rates and in some cases, such as life insurance premiums, they are kept constant in absolute terms (2.5 million liras $=1,290$ euros). Finally, the no tax area has grown thanks to the introduction of tax expenditures by types of income (8,000 euros for dependent workers and retired people).

Concluding, the described factors explain the slight increase in the progressivity of the personal income tax; this result is also confirmed by concentration indexes.

\section{Local Property Taxation}

Local services have a significant impact on people's daily life. They are supplied not only to resident people but also to tourists and people commuting for various reasons (this is why, for example, a tourist tax is applied by local governments). Most services are classified as public goods, non-rivals and non-excludable. But, also excludable services produce relevant externalities.

Local public services may be supplied in a way more differentiated and adjusted to the need of special categories of citizens than "pure" public goods (such as justice, public-order, and defense), or social security, health and education which should provide uniform services. As a consequence, for local public services the ability-to-pay and benefit principle have to coexist. As a consequence, a question to be answered is: are incomes, consumption or properties more closely-related to local public services?

The answer may be that immovable properties have a stricter relation to local public services, due to their value or price, or from the usufructuary/owner point of view ${ }^{4}$. In France, there are two different taxes: the tax fonciere, levied on the owner, and the taxe d'habitation, levied on the usufructuary. If an owner lives in the house, he pays both the taxe d'habitation and the taxe fonciere, but he benefits from a tax relief. The taxe d'habitation's tax revenue is devolved to municipalities; on the contrary, the taxe fonciere is devolved to the department and regions. Therefore, the introduction of the local tax "Tasi” (tax on indivisible services) together with IMU (tax on property), in Italy, is justified, even if the same tax revenue may have been raised levying only one tax, split between the owner and the usufructuary into percentages decided freely by municipalities.

Moreover, local public services are non-rival but excludable, as consumers pay a fee to use services; nevertheless, they may produce negative and positive externalities. For example, public transport, nursery

\footnotetext{
$343 \%$ remains higher than that tax rate for most taxpayers who, in 1978, belonged to the tax bracket 17-50 million liras (the tax rates for this bracket were $33 \%$ and $42 \%)$.

${ }^{4}$ Messina and Savegnago $(2014,2015)$ issue the reasons why some taxpayers prefer local property taxation, on the basis of the existence of a tax benefit, the stability of tax revenue and a moderate possibility to evade. Nevertheless, it is also questioned its incompatibility with redistributive aims.
} 
schools, drivability, social assistance, fight against poverty, waste management, and cultural services, in other words local services mainly benefit people other than owners. These people, thus, should not be excluded from local taxation. The owners of houses benefitting from local public services are estimated to be almost 30 million, but citizens interested in local public services are all residents, about 60 million, rather than taxpayers paying the personal income tax (Irpef), about 43 million. Therefore, local taxation should not be levied barely on real estate.

Local property taxation has probably increased as people may own property in a jurisdiction but may not be resident or domiciled in that jurisdiction. As a consequence, the correspondence between the political system (taxation and vote of exchange) and local citizens is less stringent.

In addition, it is greatly desirable that the design of property taxation, the main source of local tax revenue, are based on both the ability-to-pay principle and benefit principle, in order to prevent an excessive tax burden. To reach this scope, it is also essential to bring cadastral rents closer to market values. Nevertheless, cadastral rents have not been updated yet, even if it the revision was established by the draft enabling law 2013-2015 on tax issues; it has been put aside on the basis of the benefit principle in relation to property values.

On average, cadastral values are around $45 \%$ of their market values ${ }^{5}$; according to the age of the property and the area where it is located, discrepancies among cadastral values may get significantly above and below the average value. For example, in the South of Italy, the extreme situation may occur in which property market values are below cadastral rents.

However, the redistributive aim is the most relevant issue in favour of the necessity to update cadastral rents: The underestimation of rents is not uniform across the country, even across municipalities, and it favours high value houses and areas rather than new houses and the periphery of cities. As a consequence, whatever tax based on cadastral values implies an adverse redistribution, against less rich people living in the periphery of cities.

As far as the main residence is concerned, first Berlusconi's government and then Renzi's government exempted it from paying property taxes, in order to raise political support rather than to pursue a strategic tax design. In France, as we underlined before, taxpayers pay two taxes-even if reduced-as owner and usufructuary, while, in Italy, the owner does not pay any tax (except for the waste tax). In the literature, the exemption for the principal residence is justified by the fact that it does not generate an income for the owner. The argument is not enough compelling, especially if we consider that any empty houses do not generate incomes, therefore they should be exempted from paying property taxes.

Some owners could have illiquidity problems, for example old people, hired people, or people who have suffered a reduction in income. The tax burden could be excessive and conflicting with the basic logic of personal income taxation, if taxpayers have to pay taxes on the basis of incomes that they did not earn and taking into account that it is not easy to transform quickly a property into the monetary liquidity necessary to pay taxes.

The situation is even more complex, if we consider an owner commuting to a new jurisdiction, for example to work there, and renting a house. It may be supposed that the rent he pays is compensated by

\footnotetext{
${ }^{5}$ See "Gli immobili in Italia-2015" edited by the Department of Finance (MEF) and the Revenue Agency. We underline that before the multiplier of cadastral rents was increased from 100 to 160 - to compute the property tax base- the discrepancy was even higher, but the relative differences are unaltered.
} 
the income he earns from his own property. However, the marginal tax rate of personal income tax (Irpef-in Italy it is high for lower incomes too) or a flat tax (cedolare secca) would be applied to property income together with the higher local property tax applied to the "second residence". These anomalous situations occurred also in the past when a different property tax was applied (ICI), as municipalities differentiated the property tax rates applied to a owner-occupied residence from the property tax rates applied to a second residence. The recent property taxation—with a total exemption of the main residence-amplifies the described distortions ${ }^{6}$.

The new legislation on property taxation creates other distributional issues also in relation to some cadastral categories: A1 (stately home), A8 (villa), and A9 (castles), which are not exempted from paying the property tax. If the policy maker aims at favouring the owner-occupied residence, it is difficult to find reasons for the exclusion of those categories. A paradox may occur: a non-exempted flat could have a cadastral value higher than an exempted one, against the principle of equity. It would therefore be better to apply a high tax credit on property tax (for example 1,000 euros; five times the value of Tasi 2014), disregarding the cadastral categories. The same results would be reached in terms of tax revenue, but the whole system would be fairer.

\section{Property Taxation in Force in Italy}

State taxation that is not shared with municipalities is not fulfilling. Tax burden on property transfers is relatively high, limiting the volume of transactions; while, tax burden on rents is frequently evaded and the introduction of an optional low flat rate reduces tax evasion only slightly (and it is applicable only on houses, with exclusion of shops, stockrooms, garages, offices).

In general, Italian policy maker has been quite impromptu in designing property taxation scheme over the last years, changing frequently the tax base and the tax rates of the local and state property taxation. As far as direct state taxation is concerned (PIT IRPEF and "cedolare secca” substitute tax), property incomes—notional or actual—have been frequently adjusted, once including and once excluding them from the calculation of total income, or once levying on them progressive tax rates and once levying proportional ones. This frenetic legislative production concerning direct taxation probably attempted to join up with the chaotic changes of local property taxation (ICI, IMU, and TASI).

Italian policy maker moved from rather homogeneous personal income taxation, based on cadastral or actual rents, to a very uneven taxation, as follows:

- On rents are levied: local property taxes and the optional substitute tax rate (cedolare secca) at $21 \%$ or $10 \%{ }^{7}$.

- Rents which taxpayers do not opt to pay for the optional substitute tax and incomes from properties other than houses are included in the calculation of total income for personal income tax (Irpef) and thus they are subject to the relative marginal/effective tax rates. In addition they are subject to the stamp duty.

- $50 \%$ of cadastral rents related to empty houses in the same municipality of residence are included in the calculation of total income for PIT.

\footnotetext{
${ }^{6}$ For this and other reasons, in Italy most spouses—who are not divorced-do not reside in the same house, altering the redistributive effect and the demographic and vital statistics.

${ }^{7}$ Rents, however, are still included in the total personal income tax base which tax credit is applied to, decreasing with the kind and amount of income and the number of dependent family members.
} 
All the other empty properties are not included in the tax base of the PIT or subject to the substitute tax.

As far as state taxation is concerned, the scheme includes further taxes on real estate transfers (such as the value-added tax on the purchase of new buildings and the stamp duty on transfers; these are based on the total house's value and levied on the purchasers rather than on sellers); they are higher compared to taxes on inheritance and gift (the mortgage registration and cadastral fees).

As far as local taxation is concerned, property taxes are the most relevant source of tax revenue. But, the taxation scheme of the owner-occupied houses has been exposed to frequent changes. The most surprising change is the establishment of two property taxes (IMU and TASI), paradoxically called "single tax", probably to levy a reduced property tax on the main residence without calling it "IMU".

However, the local tax scheme brings in also a personal income surtax which, even if it is not supposed to be linked to a property tax base, at the end it is also a tax on property, when the cadastral rent is included in the state personal income tax base.

It is worth observing that a higher share of the total tax burden is levied on rented houses (maximus IMU and marginal PIT tax rates, as well substitute ones) rather than on empty houses (on which only IMU is levied). This creates a significant disincentive to rent houses and fosters tax evasion.

\section{The Incidence of Property Taxes on Property Incomes}

On these premises, it is worthwhile to think about a reform of property taxation. To this purpose, the total tax burden on property is estimated as a percentage of property incomes (actual or notional); in particular, property incomes at market values are employed rather than cadastral values. The estimation is realized by using a microsimulation model ${ }^{8}$ and integrating data from a survey on household incomes carried on by the Italian National Institute of Statistics (SILC-Istat) with the administrative data from the Department of Finance and the Cadastre. Cadastral rents are evaluated to be $8 \%$ of market ones, as they are not updated. The application of a multiplier equal to 160 to cadastral rents does not bring them up to market values. Cadastral rents still are calculated less than $50 \%$ of market ones, as cadastral incomes are only $1 \%$ of cadastral values (the ratio would be even lower using market values); on the contrary, the observed average market return is about $3.5 \%$ of cadastral value of the buildings.

Actually, taking into account the different taxes on real estate, including an annual estimation of real estate transfer taxes (which are occasional), the implicit tax rate on property market incomes is less than $20 \%$. This implicit tax rate is computed by summing all taxes up and comparing this sum to the annual market incomes; it is lower than other personal income tax rates (principally incomes earned by dependent workers, but also self-employed, pensions, dividends, and capital gains) ${ }^{9}$.

Table 1 shows the tax burden of every single tax (2014-2016) estimated by the Department of Finance (2017).

\footnotetext{
${ }^{8}$ For further details see Nicola, Mongelli, and Pellegrino (2015). We underline that thanks to the exact match between statistical data SILC (Istat), including a market rent evaluation, and administrative ones, with cadastral rents, it is possible to estimate the discrepancy and take into account every property of the sampled subjects, regardless of their reticence in answering to the interview questions.

${ }^{9}$ When computing the personal income tax on a specific income, the organization of incomes to which tax rates are applied is relevant. Therefore, diverse estimations may result.
} 
Table 1

Tax Revenue by Property Tax (Billion Euros)

\begin{tabular}{llll}
\hline & \multicolumn{3}{c}{ Total (billion euro) } \\
\cline { 2 - 4 } & 2014 & 2015 & 7.63 \\
\hline Income taxes (1) & 7.54 & 7.57 & 5.56 \\
-PIT & 5.78 & 5.50 & 2.07 \\
- “Cedolare secca” (optional flat tax on house rents) & 1.76 & 2.07 & 19.9 \\
Local property taxes (2) & 24.8 & 24.9 & 18.8 \\
-IMU & 20.1 & 20.1 & 1.1 \\
-TASI & 4.7 & 4.8 & 10.6 \\
Real estate indirect and transfer taxes (3) & 9.6 & 10.2 & 5.34 \\
-VAT on the purchase of new houses & 4.43 & 4.65 & 2.75 \\
-Stamp duties on transfers & 2.24 & 2.35 & 0.84 \\
-Stamp duties on rents & 0.88 & 0.88 & 1.53 \\
-The mortgage registration and cadastral fees & 1.47 & 1.50 & 0.72 \\
-Inheritance and gift & 0.58 & 0.67 & 38.8 \\
Total (1) + (2) + (3) & 42.6 & 43.2 & \\
\hline
\end{tabular}

Source: Elaborations on data of the Department of finance.

By computing the total property taxation (38.8 billion euros) ratio to total market tax base-actual and notional—estimated by the microsimulation model to be almost 213 billion, the resulting tax rate is $18.5 \%$.

These results seem to suggest that property taxation has to be revised urgently and deeply, rather than reduced. This is the pillar of our proposed tax reforms.

An excessive tax burden on transfers, considering also that it weighs on purchasers rather than on owners earning capital gains, reduces the efficiency of property market (lowering an optimal mobility) and at the same time creates distortions (as capital gains realized on financial assets are subject to a different and variable taxation design, according to the different categories).

\section{Two Reforms of Property Taxation Scheme}

In the light of these results, two alternative reforms of property taxation are proposed, using the microsimulation model of the Department of Finance. They aim at overcoming the limits highlighted in the previous sections and focusing on property transfers and local taxation. Tax revenue is assumed to be constant into the two scenarios.

One pillar of the two proposals is market instead of cadastral values, waiting for an updating of the cadastral dataset and being aware of the maintenance costs of properties, the existence of residual mortgages and the estimation errors.

Market values are approximated by an indicator (OMI) computed by the "Real Estate Market Observatory of the Revenue Agency" and reduced by $10 \%$ for precautionary statistical reasons of tolerance or confidence. The transformation of this value (OMI minus 10\%) into property income, if necessary, is made by applying an average return rate equal to 3.5\%, derived from the integrated dataset employed for the microsimulation.

The scheme proposing a state property tax, in addition, requires to subtract from the market property value the residual mortgage, in order to have the annual net value of property relevant for the owner. 
The two proposals suggest basing local taxation on a lower property tax-without any difference between primary and secondary residence — and replacing the current additional local personal income tax (a percentage of tax base) with a local surtax (a percentage of PIT). Therefore, in general, the proposed taxation scheme is not grounded on the property taxation but on the local personal income taxation; as a consequence, the property tax revenue (IMU/TASI) would be reduced and compensated by the local personal income taxation.

The replacement of current additional local personal income tax with a local surtax aims at:

(1) Simplifying the present heterogeneity of local taxation designs;

(2) Overcoming the "poverty trap", due to the jump to a marginal tax rate higher than $100 \%$, at the present caused by the computation of the additional local PIT on the total tax base and by the exemption linked to a zero net personal income tax ${ }^{10}$;

(3) Making local taxation more progressive and coherent with the national redistributive profile of PIT (Irpef), leaving to the municipalities the autonomy to establish the desired tax rates and to fix the range within which tax revenue may variate.

A common trait of the two proposed taxation reforms is the significant reduction of property transfer taxation. Taxpayers would pay a fix amount of property and cadastral stamp duties and registration fees, as recently suggested by NENS (2015), according to their income tax brackets, on the basis of the theoretical principle establishing that they have to cover tax administrative costs. The purchase of new houses also would be subject to this scheme or to a relatively low value-added tax.

Property transfers or property inheritance and gift may be taxed by taking into account the capital gains accumulated over the past years by the owner: he should pay therefore taxes rather than the purchaser. Only if the transfer appears to be anomalous, for example too sudden or unexpected, an additional tax could be levied, as today, in order to tax speculative behaviour. Capital gain taxation for property may be equalized to capital gain taxation established for different kind of assets such as qualified shares: a $20 \%$ tax rate is applied to $50 \%$ of capital gains, in a way more coherent with the general national taxation scheme.

Inheritance taxation-less heavy among the property transfer taxes, also comparing Italy to other countries-would be established in a way coherent with the reform proposal. Inheritance tax base would be computed using the estimated and reduced property market values and keeping constant the current tax rates and thresholds, in order to increase its tax revenue and compensate the reduction of stamp duty and registration fee tax revenue.

Finally, a further common trait of the two proposals would be the use of Cadastre in order to assess the property income taxation and the significant cutback of the current double taxation-on income and property (increased) - according to the two alternative criteria of state taxation (family property or income relevant for income tax). Actually, renting a flat and reporting it would have the same tax burden of empty houses, just like primary and secondary residence which would also have the same tax burden. As a consequence, the number of rented houses should increase and rents should lessen.

\section{The Scheme Based on the Taxation of Family Properties}

The peculiarity of this scheme would be a state property taxation on family basis, replacing any income tax and being progressive according to property market values (reduced by $10 \%$, as already underlined, for statistical tolerance), net of residual mortgages and structured as follows:

\footnotetext{
10 The additional local personal income tax is not due if the total net personal income tax is null.
} 
- Family allowance equal to 170,000 euros (zero tax-rate);

- $0.3 \%$ tax rate, from 170,000 to one million euros;

- $0.6 \%$ tax rate, from one million to two million euros;

- $1 \%$ tax rate, above two million euros.

This property tax would be applied to the household, not including cohabitants earning more than 7,000 euros who become part of a new household. The innovative definition of "household" for tax purposes, without cohabitants earning - yearly-more than 2,841 euros, aims at incorporating the fully-fledged components of the household, in particular low-pension retired, participating in family income and spending.

Moreover, the surtax tax rates, replacing local additional personal income tax rate, would be respectively 3.6\% (for municipalities) and 8.4\% (for regions) of the due net PIT (Irpef).

This new local "single tax" (replacing TASI and IMU) would be, on average, equal to $0.3 \%$ of property market values, for empty as well as rented or owner-occupied flats. However, this local single tax would be regressive, as secondary residences and non-residential building are owned by the top tenths of households, therefore a tax credit would be established (0.10\%) ranging from a minimum 80 euros to a maximum 240 euros $^{11}$.

The effects of this scheme were estimated by the Department of Finance tax-benefit microsimulation model, comparing the current scenario with the proposed one. From the point of view of tax revenue, the relevant changes are shown in Table 2.

Table 2

The Effects of the Introduction of a Household Single Property Tax-Tax Revenue Variations

\begin{tabular}{lll}
\hline & Frequence & Million euros \\
\hline Net state personal income tax & $7,124,864$ & $-7,063$ \\
Abolition of the flat tax on rents (cedolare secca) & $1,085,279$ & $-1,572$ \\
Variation of "family allowances" (due to the variation of income tax bases) & $3,276,670$ & +465 \\
Variation due to surtax vs. local additional personal & $29,857,874$ & +716 \\
Property taxation (TASI/IMU) changes & $26,237,661$ & -779 \\
Individual property tax & $15,432,847$ & $+9,534$ \\
Disposable income changes & $36,958,674$ & -241 \\
\hline
\end{tabular}

Source: Department of finance microsimulation model.

Data show a reduction in rent taxation (actual or notional), compensated by a balance between local taxation on the basis of personal income taxation and property taxation.

From a redistributive point of view, opposed effects are registered. Reductions of the current progressive taxes are set against the introduction of a progressive property tax (property tax on the secondary residence_-IMU—and local personal income taxation or flat tax on rents—cedolare secca).

Figure 1 shows the incidence of the variations generated by the reform of property taxation on incomes, by equivalent tenths.

\footnotetext{
11 This system is preferable to a flat tax credit, applied when a different property tax (ICI) was in force: It tended to reduce too much the tax revenue in the smaller municipalities, where around $50 \%$ of residents did not pay the tax, while decreasing excessively in the greater municipalities.
} 


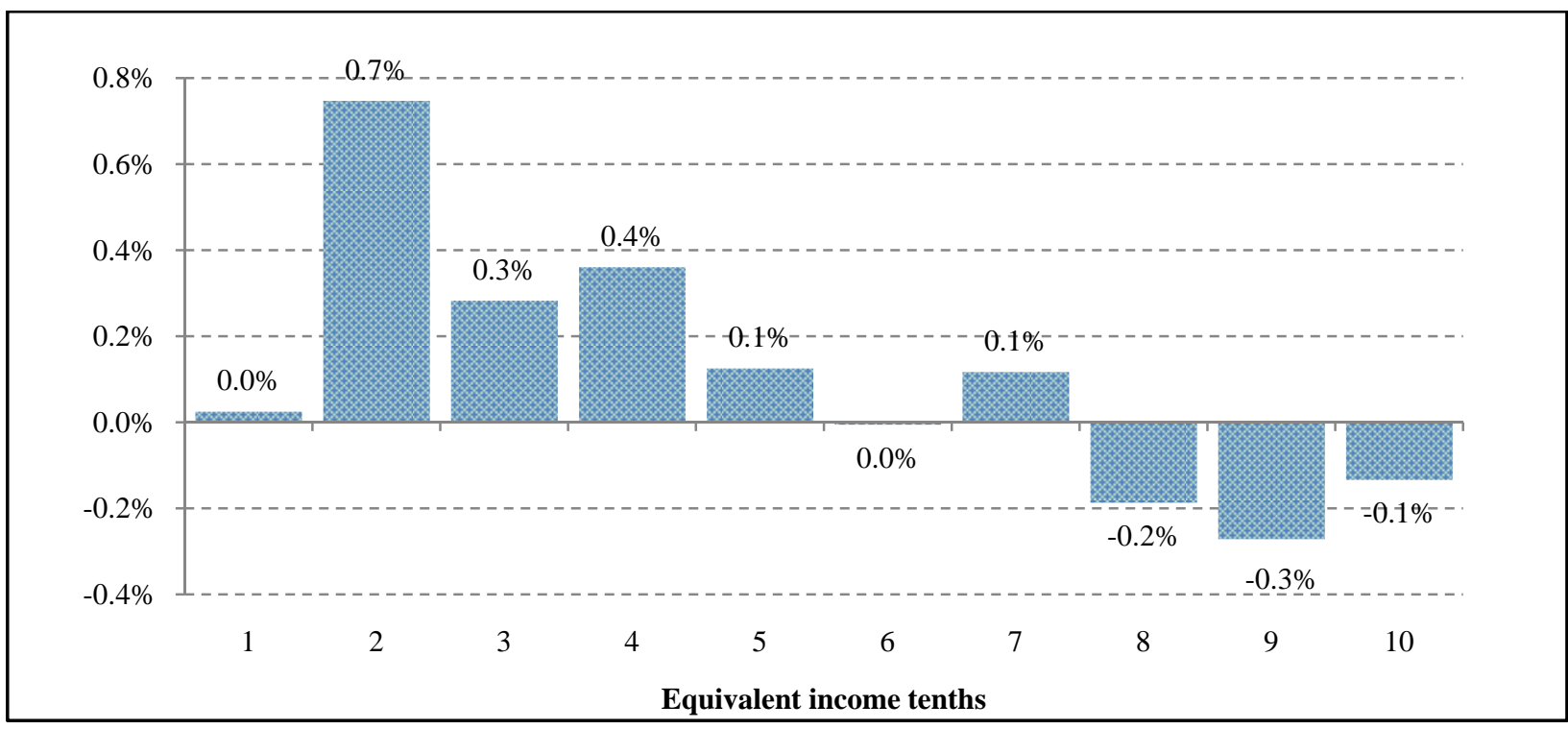

Figure 1. Incidence on incomes (\%) of variations of disposable income (property tax based reform) by equivalent income tenths.

It is possible to observe a twofold redistributive trend; the impact is advantageous for the first seven tenths and adverse for the three top tenths.

\section{Property Actual and Notional Incomes Included in the PIT}

The second proposed reform scheme is based on the partial inclusion of notional property incomes (market values) in the PIT (Irpef).

The general tendency to exclude property incomes from the total tax base for income tax (comprehensive income tax), over the past few years, in consequence of the increasing burden of local property tax, opposes some relevant objectives of income redistribution and ability to pay. The exclusion of significant shares of incomes from the personal income taxation is a question frequently brought up to suggest an attenuation of income redistribution and a switch from a progressive tax to a flat tax.

In order to get closer to a comprehensive income tax and make the property tax more progressive, we attempt to advance a scenario which, provided that local taxation proposed by the first scheme is also implemented (a property tax-IMU—with the same tax rates but lower than the current ones, the surtax replacing local additional personal income tax for an equal tax revenue), does not introduce a property tax and includes notional property market incomes in the PIT, reduced by $30 \%$ to take account of property maintenance costs, for precautionary statistical reasons. Finally, we compare the two proposed reforms.

As in the first proposed scheme, the reduced property notional incomes (based on market values) would be included in the PIT whether the house is rented or not, in order to guarantee the necessary neutrality.

In addition, it is very important, when using imputed values, to take account of the liquidity risk for taxpayers: including them in the PIT, with tax credits, exemptions and progressivity, would prevent the liquidity risk and would adhere to the actual ability-to-pay. A progressive tax rate on a more comprehensive income would exempt lower incomes, as proposed under the two reform schemes.

Local surtaxes linked to the personal income tax would be respectively equal to $3.4 \%$ (for municipalities) and $7.9 \%$ (for regions). They would be reduced to compensate the effects of a higher personal income tax, in 
this scenario, while property tax and property transfer tax would be structured as in the other proposed tax scheme.

Table 3 shows the tax revenue variations according to every proposed tax change, estimated by the Department of Finance microsimulation model.

Table 3

Changes From the Proposed Personal Income Taxation Scheme

\begin{tabular}{lll}
\hline & Numero & Saldi (milioni) \\
\hline Net state personal income tax & $7,605,070$ & $+2,066$ \\
Abolition of the flat tax on rents (cedolare secca) & $1,085,279$ & $-1,572$ \\
Variation of "family allowances" (due to the variation of income tax bases) & $3,176,905$ & +357 \\
Variation due to surtax vs. local additional personal income tax & $29,990,982$ & +672 \\
Property taxation (TASI/IMU) changes & $26,237,661$ & -779 \\
Disposable income changes & $37,016,784$ & -35 \\
\hline
\end{tabular}

Source: Department of finance microsimulation model.

It is necessary to clarify that the personal income tax paid by households depends upon the inclusion of the notional property income and the exclusion of the effective property income; on the contrary, the latter has to be included in the PIT according to the current legislation. These changes also affect indirectly the amount of family allowances, linked with a specific notion of income.

From a redistributive point of view, conflicting effects are registered. Reductions of the current progressive taxes (property tax on secondary residence-IMU—and local personal income taxation or flat tax on rents - cedolare secca) are set against the introduction of property incomes in the personal income tax.

Figure 2 shows the effects of the proposed changes by equivalent income tenths.

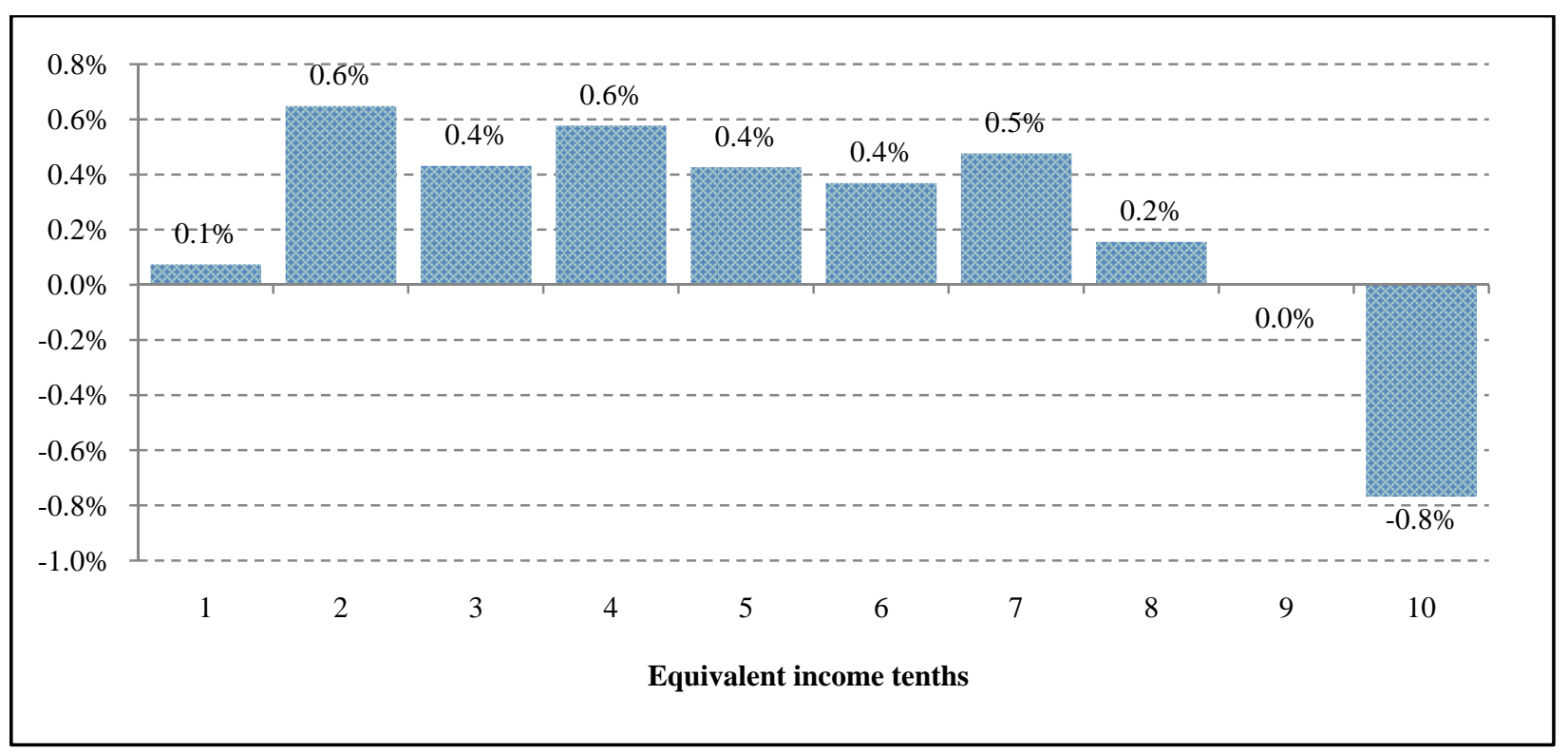

Figure 2. Incidence of variations of disposable incomes (PIT based reform).

In this case, the redistributive effect is more intense and uniform.

Figure 3 compares the two proposed tax schemes for property taxation. 


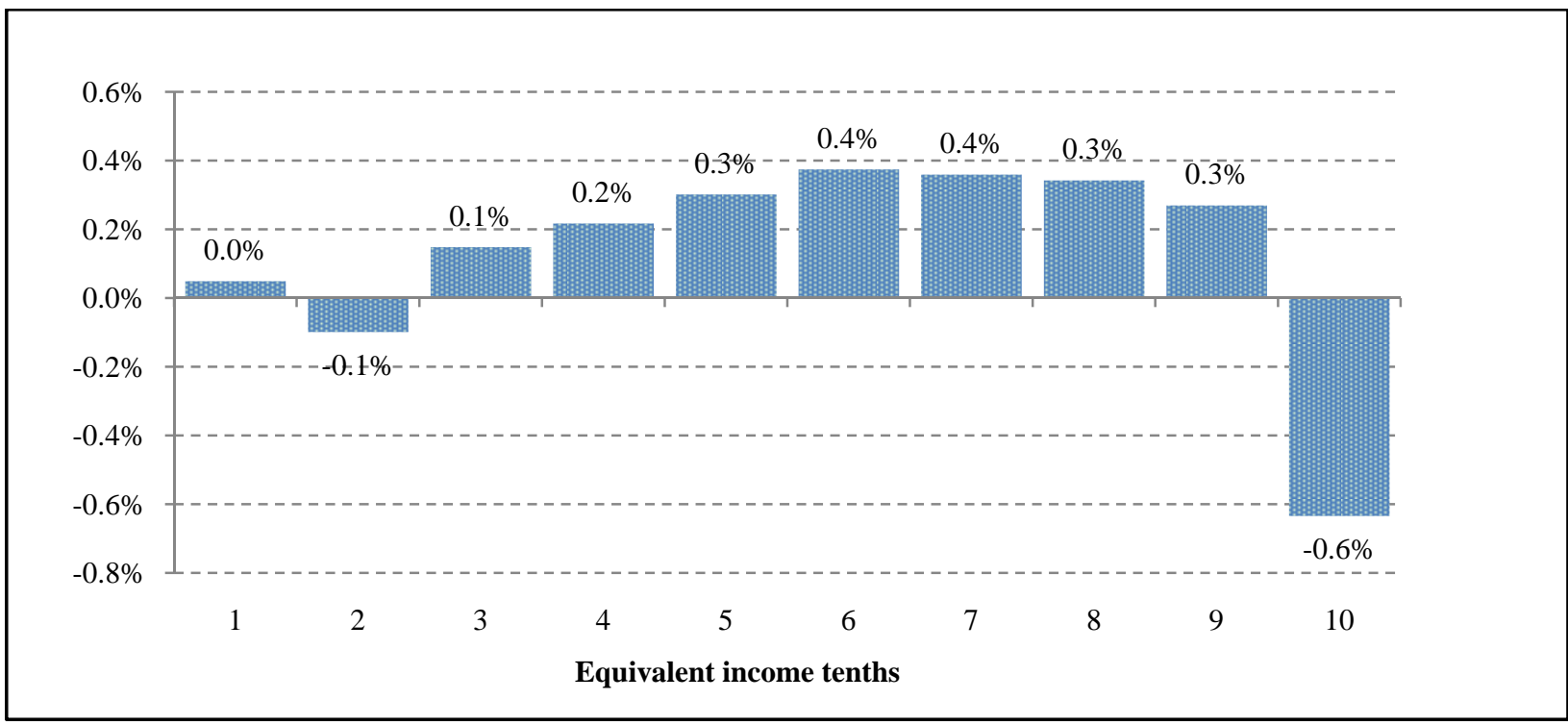

Figure 3. Incidence on incomes (\%) of variations of disposable incomes-Personal income tax vs. property tax.

The personal income tax design has a greater impact-in terms of income redistribution-than the property tax design, keeping constant their tax revenue. There are lots of reasons, for example: the pertinence of the suggested personal income tax designed to the indicators of redistribution computed on incomes (equivalent), the fundamental different combination of property and income and the diverse units of observation, the family for the property tax and the individual for the personal income tax.

Finally, the Gini coefficient, a synthetic indicator traditionally less reactive when the reforms of the current tax schemes concern the same country and are not radical, registers a concentration ratio of disposable incomes equal to $41.51 \%$ at the current state, equal to $41.38 \%$ in the proposed property tax scheme and equal to 41.13\% in the personal income tax scheme. Therefore, the Gini coefficient is coherent with the data on the redistributive effects shown in Figures 2 and 3.

\section{Conclusion}

Starting from the analysis of the diverse approaches concerning the property and income taxation, for example the supplementary property taxation or comprehensive income taxation, two reform schemes were recommended aiming at overcoming the lack of the current property taxation: distort evaluation of property tax bases, non-optimal allocation of local property taxes, non-optimal local personal taxes, an excessive and ineffective tax burden of stamp duties and registry fees.

On these assumptions, two different scenarios were compared, both based on changes aimed at a) taking into account capital gains earned by owners and notional property incomes, balancing property and income taxation; b) transforming the local additional personal income tax into surtax; c) repealing the supplementary taxation of rents.

In the first scenario a progressive property tax, based on household income, is analysed.

In the second scenario, notional property incomes are included in the national personal income tax base, keeping the tax revenue constant and excluding actual rents.

The results of our estimation show, beyond the expected higher effectiveness of the proposed tax designs, a higher redistributive effect of both tax schemes. In particular, progressive property tax, based on household 
income, has a stronger redistributive effect. The conclusive policy suggestion is that it is not relevant to identify the best tax scheme between the two proposed ones but to intervene rapidly in order to change the unsatisfactory current tax design into a more coherent one.

\section{References}

De Vincenti, C., \& Paladini, R. (2009). Personal income tax design for Italy: Lessons from the theory. Rivista Italiana degli Economisti, 1.

Di Nicola, F., Mongelli, G., \& Pellegrino, S. (2015). The static microsimulation model of the Italian Department of Finance: Structure and first results regarding income and housing taxation. Italian Journal of Public Economics, 2. Milano: Franco Angeli Ed.

Diamond, P. (1998). Optimal income taxation: An example with a u-shaped pattern of optimal marginal tax rates. American Economic Review, 88.

Dipartimento delle Finanze MEF, Agenzia delle Entrate. (2017). Gli immobili in Italia (Real estate in Italy), Rome, Italy.

Hall, R., \& Rabushka, A. (1983). Low tax, simple tax, flat tax. New York: McGraw Hill.

Meade, J. (1978). Report on the structure and reform of direct taxation. IFS, London, UK.

Meade, J. (1989). Agathotopia: The economics of partnership. Aberdeen University Press.

Messina, G., \& Savegnago, M. (2014). A prova di acronimo: i tributi locali sulla casa in Italia. Questioni di economia e finanza, 250, Banca d'Italia.

Messina, G., \& Savegnago, M. (2015). Residential home taxation in Italy, a difficult equilibrium among decentralization and redistribution. Italian Journalof Public Economics, n.3-2015. Milan, Italy: Franco Angeli Ed.

Mirrlees, J. (1971). An exploration in the optimum income taxation. Review of Economic Studies, 3.

NENS. (2015). Una revisione dell'imposizione immobiliare. Retrieved from http://www.nens.it/zone/pagina.php?ID=8\&ID_pgn=1028\&ctg1=Dossier\&ctg2=Nessuna

OECD Working Party on Private Pensions. (2005). Private pensions: OECD classification and glossary, OECD, Paris, France.

Piketty, T. (2014). Capital in twenty first century. Massachussets, USA: Harvard UniversityPress.

Piketty, T., Saez, E., \& Stantcheva, S. (2013). Optimal taxation of top labor incomes: A tale of three elasticities. American Economic Journal: Economic Policy.

Saez, E. (2001). Optimal income taxation: An example with a u-shaped pattern of optimal marginal tax rates. Review of Economics Studies, 68.

Simons, H. (1938). Personal income taxation: The definition of income as a problem of fiscal policy. Chicago: University of Chicago Press.

Vickrey, W. (1947). Resource distribution patterns and the classification of families. NBER Chapters, In Studies in income and wealth (pp. 266-297). National Bureau of Economic Research, Inc.

Visco, V. (2014). Report at Conference Rethinking the Left. Rome (Italy). Retrieved from http://www.ripensarelasinistra.it/il-futuro-e-il-passato-del-principio-di-progressivita-delle-imposte/ 